\title{
Assessing Fecal Contamination in Groundwater from the Tulum Region, Quintana Roo, Mexico
}

\author{
Rosa Ma. Leal-Bautista ${ }^{1}$, Melissa Lenczewski ${ }^{2}$, Cheyenne Morgan ${ }^{2}$, Amy Gahala ${ }^{2}$, Jean E. McLain ${ }^{3}$ \\ ${ }^{1}$ Centro de Investigacion Cientifica de Yucatan, Unidad de Ciencias del Agua, Cancun, Quintana Roo, Mexico; ${ }^{2}$ Northern Illinois \\ University, Department of Geology and Environmental Geosciences, DeKalb, USA; ${ }^{3}$ University of Arizona Water Resources Re- \\ search Center, Tucson, USA. \\ Email: rleal@cicy.mx
}

Received August $16^{\text {th }}, 2013$; revised September $17^{\text {th }}, 2013$; accepted October $15^{\text {th }}, 2013$

Copyright (C) 2013 Rosa Ma. Leal-Bautista et al. This is an open access article distributed under the Creative Commons Attribution License, which permits unrestricted use, distribution, and reproduction in any medium, provided the original work is properly cited.

\begin{abstract}
The Yucatan Peninsula's groundwater is experiencing increases in degradation due to swelling population and tourism; yet little is known about sources and transport of contaminants in drinking water supplies. The karst allows for rapid transport of microbial and chemical contaminants to the subsurface, resulting in significantly increased potential for pollution of groundwater. The objective of this research is to determine the occurrence, source, and extent of fecal contamination in the Tulum region of the Peninsula. A multi-analytical approach was undertaken in impacted and unimpacted groundwater locations; measurements included physicochemical parameters, total coliform and E. coli, Bacteroides (human vs total) and caffeine. The results indicate a variation in geochemistry from impacted to protected sites. The total coliform and E. coli show fecal contamination is wide spread. However, the presence of human Bacteriodes and caffeine in the water in the Tulum well field indicates that the recent human activities next to the well field are impacting the drinking water supply. This project is an assessment of the area's current water quality conditions and the probable impact that the aforementioned growth would have on the area's water supply. By applying multiple source parameter measurements, including molecular microbiology and chemical indicators it was confirmed the extent of fecal contamination of human origin covered the entire sampling region.
\end{abstract}

Keywords: Groundwater; Microbial; Chemical Contaminants; Transport; Yucatan Peninsula; Quintana Roo

\section{Introduction}

The groundwater of the Yucatan Peninsula (YP) is undergoing severe degradation due to increasing population and tourism; yet little is known about sources and transport of contaminants that are impacting drinking water supplies. The geology of the region is a highly permeable fractured limestone or karst that allows for rapid transport of microbial and chemical contaminants to the subsurface, resulting in significantly increased potential for pollution of groundwater [1-3]. In a karst aquifer, such unrestricted contaminant transport may complicate efforts to identify pollution sources, particularly when multiple sources are identified. Protection of groundwater resources in karst aquifers requires understanding of the transport of water and contaminants through the soil, epikarst, unsaturated zone and active conduit network to drinking water extraction points [4].

The regional aquifer that underlies the Peninsula of
Yucatan is one of the largest regional aquifers in Mexico [5]. It is also one of the most vulnerable aquifers to anthropogenic contamination. A common practice in the YP is to dispose of raw sewage through deep-water injection, in which wells are drilled to approximately 80 meters below land surface, and the untreated or primary treated sewage is injected into saline water. The introduction of these pollutants into lower density, higher temperature water, increases the risk that the water with the sewage may rise over time contaminating the aquifer from the bottom up. There are relatively few studies on the YP concerning the human impact on the freshwater aquifer [6-12]. Research concerning contamination of the freshwater aquifer zone by both organic and inorganic substances has been conducted in the northwestern region of the peninsula particularly on the area surrounding the city of Merida [7-10]; but there is a paucity of research that has been conducted in the northeast near 
Cancun or in the Riviera Maya region [6,11-13]. Fecal contamination of the waters along Caribbean coastline was last studied more than fifteen years ago, during the early stages of the population boom [6]; and this work did not include land areas directly adjacent to Tulum.

The city of Tulum is located in the southern part of the region of the Riviera Maya and has seen rapid and uncontrolled growth in the last 5 - 10 years. Within the Tulum region the population disposes of its wastewater in multiple ways. A majority of the local residential population uses soakaways, cesspits, and septic tanks for disposal, while major hotels and resorts tend to be equipped with wastewater collection and treatment facilities [14]. While the hotels have treatment facilities, many of the hotels do not maintain the facilities beyond the initial installation and thus, a common practice has developed to dump sewage directly into mangrove swamps or inject the improperly treated wastewater into saline water just below the freshwater (authors' personal observations). The current population explosion combined with sewage disposal practices and karst geology, imparts a greater risk to households receiving potentially contaminated drinking water. Detailed study of sources and extent of groundwater contamination is necessary for mitigation to protect public health and minimize economic impacts.

The objective of this research project is to examine groundwater in the Tulum region of the YP. Sampling points range from protected to impacted to determine the occurrence, source, and extent of fecal contamination. A multi-analytical approach was used to determine the pres- ence of fecal contamination within the water supply. The most-probable-number (MPN) method was used to determine the concentration of total coliforms and E. coli. To determine if the source of the fecal contamination was human in origin, analysis for human-specific Bacteroides genetic markers and presence of caffeine as chemical indicator were used. This project is an assessment of the area's current water quality conditions and the probable impact of current and future population growth may have on the area's water supply. Knowledge of the sources of groundwater contamination and their relationship to environmental factors is critical to guide the implementation of remedial actions.

\section{Study Site}

\section{Geological and Hydrogeological Setting}

Tulum is located in the Riviera Maya that extends along the northern Caribbean coast on the eastern portion of the Yucatan Peninsula (Figure 1). The Caribbean coast of the Yucatan Peninsula is mainly made up of MiocenePliocene sedimentary deposits with a few Quaternary surficial sedimentary deposits of carbonate limestone origin. Geomorphologically, the region is flat with a series of gentle beach ridge-and-swale plains that run parallel to the coastline and extend southward along the Riviera Maya. The narrow beach ridge plain is positioned a few kilometers to the west of Puerto Juarez and runs south terminating near Xel Ha. The plain elevation is between $5-10 \mathrm{~m}$ and has a width of less than $10 \mathrm{~km}$ at its widest.

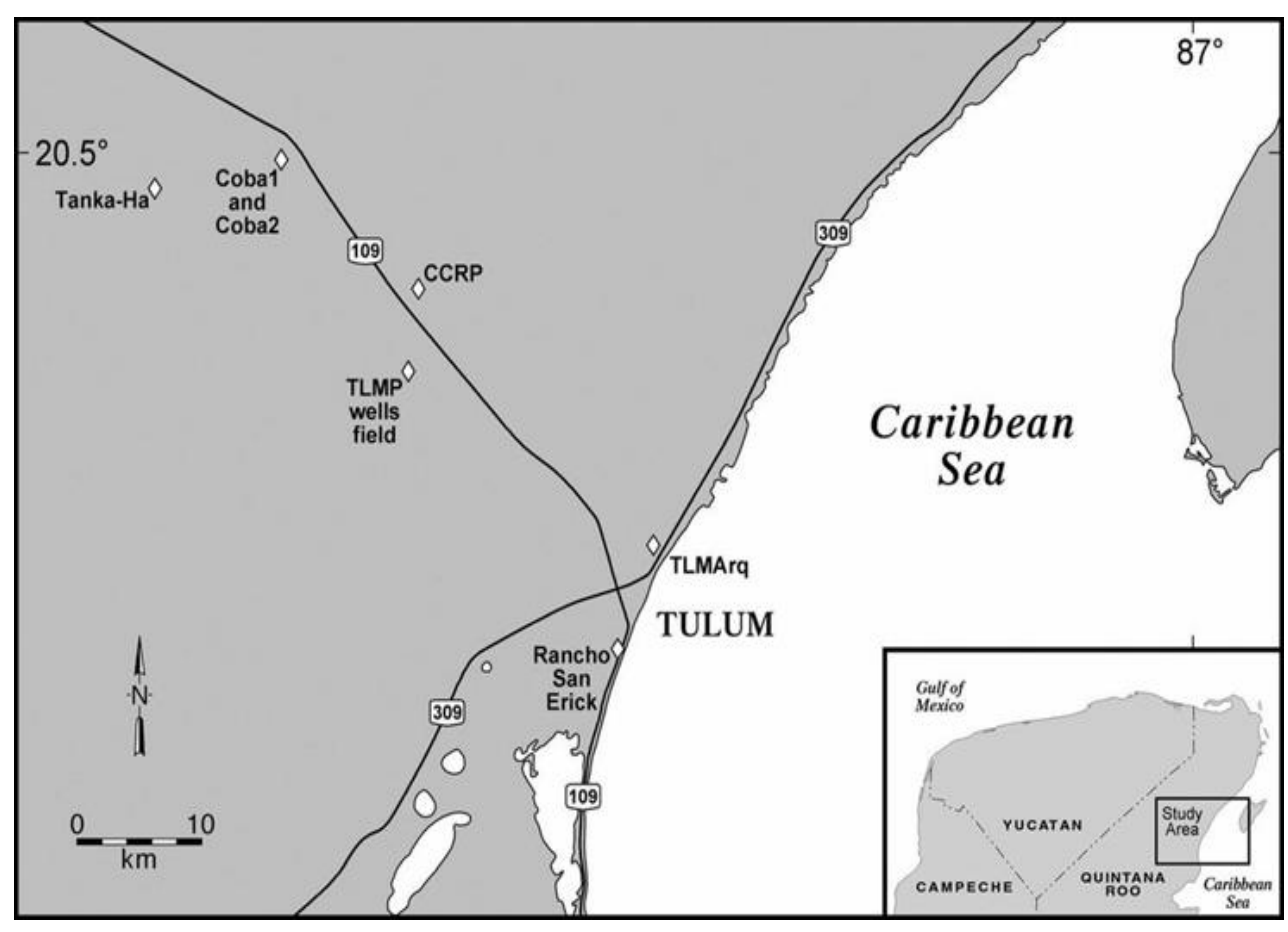

Figure 1. Map of the study are a around Tulum, Quintana Roo, Mexico. Th. 
The swales are up to $200 \mathrm{~m}$ wide and are between 2 - $5 \mathrm{~m}$ deep [15]. Ward et al. [16]; published a diagrammatic cross section based on surface geology and a few exposures located near the town of Puerto Morelos. The crosssection showed calcarenite, micrite, and limestone units separated by what was interpreted to be separate caliche boundaries. Ward et al. hypothesized that as the sea level receded a cementation process occurred that formed a limestone aquiclude (caliche). There are two caliche boundaries in their depiction, yet current theories propose that there could be up to three layers of caliche in the coastal subsurface geology [15]. These caliche layers within the subsurface have been postulated as being partially responsible for the retainment of the freshwater lens in the Yucatan aquifer despite its unconfined status [1].

The unconfined aquifer of the Yucatan Peninsula is split into three zones: the saline water zone, the mixing zone, and the freshwater lens zone. Moore et al. [17] calculated that the freshwater lens within the Tulum region had a thickness $40 \%$ less than what had been previously estimated. This smaller thickness is believed to be the result of freshwater injection of wastewater effluent below the mixing zone out to the coast. The freshwater injection changes the salinity of the brackish water located in the mixing zone as well as decreases the salinity of the water within the saline water zone [17].

The hydrogeology of the coastal aquifer allow for rapid downward infiltration and equally rapid lateral movement of water flow within the subsurface [18]. A high water table, typically only a few meters below the surface, is due to the peninsula's high porosity and flat topography [19]. Extensive fracturing and the presence of subterranean conduit systems can change the direction of groundwater flow, as evidenced along the northern and northeastern coast in the Holbox Fracture Zone (HFZ). The Tulum region is located within the southern portion of the HFZ, which contains a series of large solution depressions (over $100 \mathrm{~km}$ long) that parallel the Caribbean coast in a NNW-SSE alignment $[13,20]$. Water within the HFZ flows from the southeast to the northwest along the solution depressions which replicate the offshore ocean flow patterns along the coast [20].

The aquifer porous matrix along the Yucatan coastline maintains approximately $97.1 \%$ of the aquifer storage while the fracture flow system carries out $99.8 \%$ of the aquifer water flow [11]. There are nearly fifty subterranean conduit systems dotting the coast of Quintana Roo encompassing a total conduit length exceeding $350 \mathrm{~km}$ [11]. The shallow system, where fresh groundwater discharges from the inland out to the Caribbean coast extends from the surface down to approximately $20 \mathrm{~m}$ while the deeper level system extends down to approximately $120 \mathrm{~m}$. This system of caves is associated with the influx of saline water into the interior of the peninsula [11,21].

The Yucatan Peninsula receives approximately $150 \mathrm{~cm}$ of precipitation per year with a majority of that (more than $100 \mathrm{~cm}$ ) falling during the wet season of May-October [18]. Precipitation increases from northeast to southwest resulting in the precipitation measurements exceeding $150 \mathrm{~cm}$ within the Tulum region [15]. During the length of this study, precipitation information was collected for Quintana Roo [22,23]. Average temperatures range from $23^{\circ} \mathrm{C}$ in the winter months up to $30^{\circ} \mathrm{C}$ in the summer $[22,23]$.

\section{Material and Methods}

Groundwater samples were collected from 2008 through 2012 during low tourist/wet (May, June, August or October) and high/dry seasons (December, January, March or July). The sampling locations included 12 wells (nine municipal water supplies and two private wells) and one cenote (sinkhole) (Figure 1). The two private wells (TLMZrq and CCRP) were located inland and were not obviously impacted from coastal development. The municipal wells (TLMP 1-7 and COBA 1-2) were impacted by development near the wellheads and recharge zones. TLMP1 was an open well and was sampled with depth while TMLP 2-7 are currently drinking water wells and water was collected at valve at each well head. A tourist swimming cenote (TANK-HA) was sampled to determine the impact of swimming in the shallow groundwater.

At each location water samples were collected for analysis of total coliform and $E$. coli. The samples were tested using the IDEXX Colilert ${ }^{\mathrm{TM}}$ and IDEXX QuantiTray/ 2000 following manufacturer protocol (IDEXX Laboratories, Inc., Westbrook, ME). After collection in the field, samples were brought to the laboratory and assayed within 6 hours. In the laboratory, duplicate samples taken from the well were serially diluted (1:10, 1:50, and 1:100) and analyzed.

Water $(1-10 \mathrm{~L})$ was filtered through a $0.22 \mu \mathrm{m}$ Millipore nitrocellulose filter for extraction of total DNA for determination of Bacteroides concentrations in December, March, and July. DNA was extracted using the ZR PowerSoil DNA Isolation Kit ${ }^{\mathrm{TM}}$ (PF0982, MO BIO Laboratories, Inc., Carlsbad, CA) at Northern Illinois University following manufacturer protocol. DNA concentrations and purity were assessed using the Thermo Scientific NanoDrop 1000 Spectrophotometer and the corresponding ND-1000 v3.7.1 software (Thermo Fischer Scientific, Inc., Wilmington, DE). All Bacteroides real-time PCR analysis was conducted in the Microbial Ecology laboratory at the USDA-ARS US Arid-Land Agricultural Research Center (Maricopa, AZ). Real-time PCR was performed on sample DNA extractions to determine the relative quantities of all Bacteroides genetic markers (All- 
Bac) and human Bacteroides genetic markers (HuBac) within each sample using the assays of Seurinck et al. (2005) and Layton et al. (2006) for HuBac and AllBac, respectively. Real-time PCR analysis was conducted in 25 $\mu \mathrm{L}$ volumes composed of $12.5 \mu \mathrm{L}$ Master mix (Absolute Blue SYBR Green, Thermo Fisher Scientific, Inc., Wilmington, DE), forward and primer primers as per referenced publications, $8 \mu \mathrm{L}$ Nuclease-free $\mathrm{H}_{2} \mathrm{O}$ and $2 \mu \mathrm{L}$ of extracted DNA template. All real-time PCR assays were conducted on the Applied Biosystems 7300 Real Time PCR System (Life Technologies Corporation, Carlsbad, CA).

The extraction of caffeine was performed from a 1 liter of sample collected in an amber glass container according to modified method of [25]. The analysis was performed in $50 \mu \mathrm{L}$ injections to HPLC and UV detector (Thermofinnigan Spectra System-UV2000) using a CP10$10 \mathrm{~cm}$ column with methanol/water 35/65, $1 \mathrm{~mL} / \mathrm{min}$ flow rate, and the UV detector was set at $295 \mathrm{~nm}$.

\section{Results}

The physicochemical parameters included $\mathrm{pH}$, specific conductivity, oxidation-reduction potential (ORP), depth, and temperature (Table 1). At CCRP, both temperature $\left(25^{\circ} \mathrm{C}\right)$ and $\mathrm{pH}(6.8)$ remained constant with depth $(0-38$ $\mathrm{m}$ below water level (mbwl)). Between 32 - $34 \mathrm{mbwl}$ the specific conductivity rises from $2.4 \mathrm{mS} / \mathrm{cm}$ to $41.1 \mathrm{mS} / \mathrm{cm}$ indicating the presence of the aquifer's saline water interface. ORP increases with depth from $297 \mathrm{mV}$ to 362 $\mathrm{mV}$ indicating aerobic activity in the water column. At the well field in Tulum, the temperature ranged from $25^{\circ} \mathrm{C}$ to $28.2^{\circ} \mathrm{C}$, and $\mathrm{pH}$ ranged from 6.7 to 7.7 with depth in TLMP1. The greatest variances were observed in ORP and specific conductivity. The ORP declined with depth in December from $250 \mathrm{mV}$ to $83 \mathrm{mV}$, in July from $367 \mathrm{mV}$ to $325 \mathrm{mV}$ and in March from $200 \mathrm{mV}$ to $74 \mathrm{mV}$. The specific conductivity during December and March remains at $0.7 \mathrm{mS} / \mathrm{cm}$ regardless depth; however, for July 2009 it dropped from 0.8 to $0.1 \mathrm{mS} / \mathrm{cm}$ with depth (0 to $12 \mathrm{mbwl}$ ). The results from the other wells at the well field where consistent during all sampling periods.

The two sites that were not impacted by tourism or rapid growth (Tank-ha sinkhole and Coba) had similar results even that they are $12 \mathrm{~km}$ apart. The temperature was $25.4^{\circ} \mathrm{C}$ at Tank-ha and $25.7^{\circ} \mathrm{C}$ at Coba. The specific conductivity is $1.5 \mathrm{mS} / \mathrm{cm}$ for Coba wells and for the sinkhole it remains constant at $1.4 \mathrm{mS} / \mathrm{cm}$, and the ORP measured at Coba was $359.6 \mathrm{mV}$ and Tank-ha showed a range from 373 to $423 \mathrm{mV}$ that increase with depth (0 13 mbwl) (Figure 2).

Total coliform and E. coli were used as microbial indicators for the presence of fecal material in the groundwater (Table 2). The results showed a general trend of higher numbers during summer months (wet season) and lower levels of microbial contamination during the dry season. However, variation in these results indicates that the fecal contamination is wide-spread and variable.

Bacteroides markers were present at least once in every sampling site (Table 3). Both the highest and lowest Bacteroides markers were recorded in July. CCRP had the lowest concentration at 176 markers $/ 100 \mathrm{~mL}$ while TLMP1 had the highest concentration of markers $(103,882$ markers/100mL). All sites beyond the Tulum municipal battery (CCRP, AKCH, EWT, and WWT) were positive for Bacteroides markers. July 2009 had the highest percentage of sites sample positive (100\%). Those sites sampled in December were $33.3 \%$ positive while those sampled in March were $50 \%$ positive.

The presence of human-specific fecal contamination was assessed using the HuBac assay. Human Bacteroides markers were recorded in four samples collected in March and July (Table 3). Aside from one Tulum well field samples, human Bacteroides markers re not present in any of the December or March samples. All samples that were positive for human fecal contamination were taken in July. For this period TLMP1 had the highest number of human Bacteroides markers at 1875 markers $/ 100 \mathrm{~mL}$ and TLMP2 had the lowest number of human Bacteroides markers at 117 markers $/ 100 \mathrm{~mL}$. Caffeine, which indicates the presence of human feces, was positive during June collection (Table 4).

\section{Discussion}

Over the length of this study, visible human impact at the surface was strongly correlated with the occurrence of fecal contamination at any given site. The Tulum municipal well battery is situated between Tulum and Coba

Table 1. Physicochemical data collected at Tulum wellfield.

\begin{tabular}{|c|c|c|c|c|c|c|c|c|}
\hline \multirow{2}{*}{ Site } & \multicolumn{2}{|c|}{ Temperature $\left({ }^{\circ} \mathrm{C}\right)$} & \multicolumn{2}{|c|}{ Specific Conductivity (mS/cm) } & \multicolumn{2}{|c|}{$\mathrm{pH}$} & \multicolumn{2}{|c|}{ ORP $(\mathrm{mV})$} \\
\hline & MARCH & JULY & MARCH & JULY & MARCH & JULY & MARCH & JULY \\
\hline TLMP2 & NA & 27 & NA & 2 & NA & 7.2 & NA & 328 \\
\hline TLMP4 & 29 & 26 & 2.2 & 2.3 & 6.7 & 7.1 & 315 & 341 \\
\hline TLMP5 & 30 & 27 & 2.2 & 2.3 & 6.8 & 6.9 & 298 & 335 \\
\hline TLMP6 & 32 & 27 & 2.2 & 2.4 & 7.5 & 7.3 & 262 & 315 \\
\hline TLMP7 & 29 & 26 & 2.8 & 3 & 6.7 & 6.6 & 290 & 351 \\
\hline \multicolumn{9}{|c|}{ (NA = no data collected) } \\
\hline
\end{tabular}




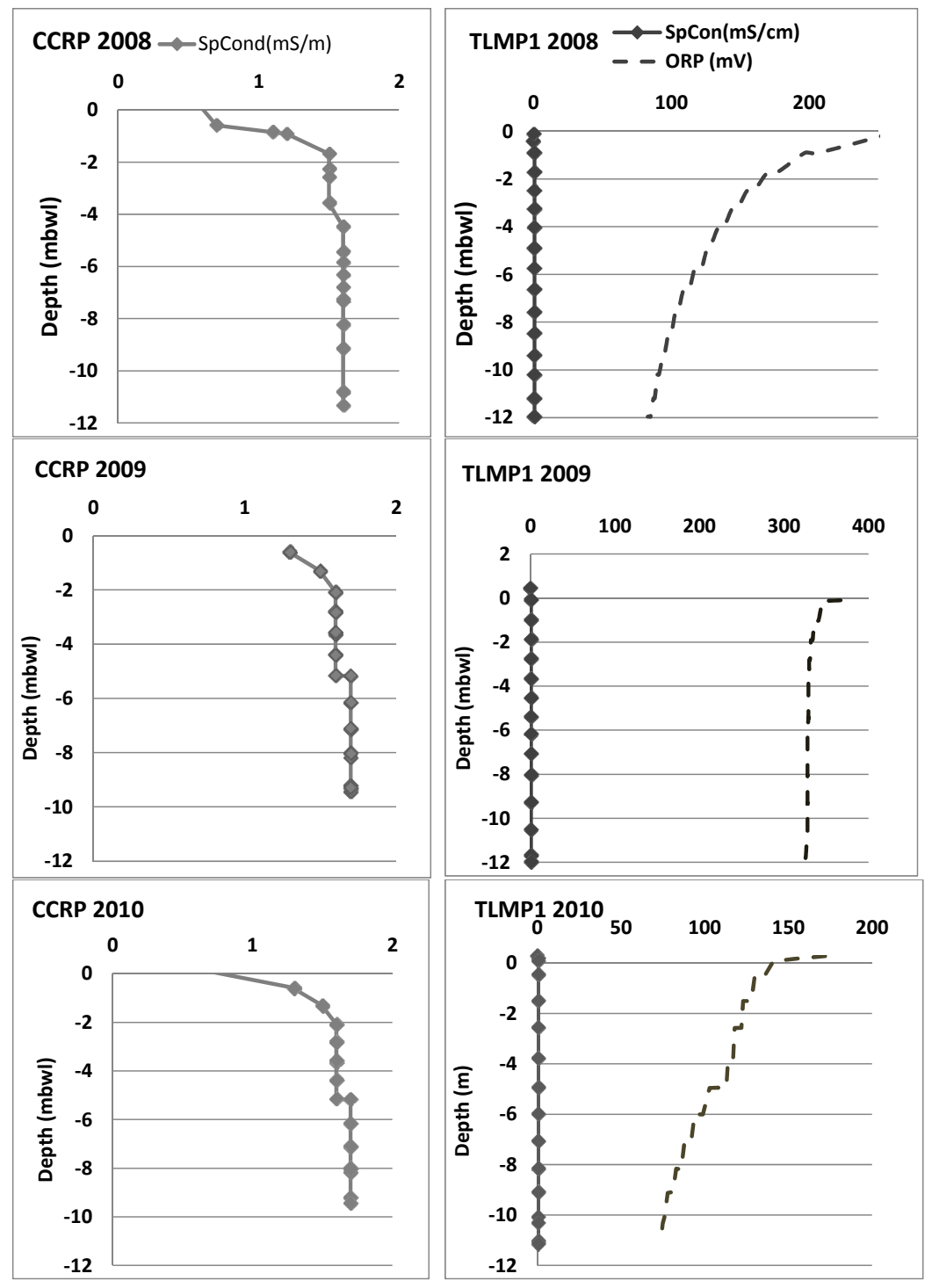

Figure 2. Geochemical profiles for conductivity and redox potential for two of the wells (CCRP and TLMP1).

Table 2. Total coliform and $E$. coli results from sampling locations and different seasons.

\begin{tabular}{|c|c|c|c|c|c|c|c|c|c|c|c|c|c|}
\hline \multirow{3}{*}{ Site } & \multirow{3}{*}{$\begin{array}{c}\text { Depth } \\
\text { (mbwl) }\end{array}$} & \multicolumn{6}{|c|}{ TOTAL COLIFORMS (MPN/100mL) } & \multicolumn{6}{|c|}{ E. coli $(\mathrm{MPN} / 100 \mathrm{~mL})$} \\
\hline & & JUNE & DEC & JUL & MAR & JAN & JUL & JUNE & DEC & JUL & MAR & JAN & JUL \\
\hline & & 2008 & 2008 & 2009 & 2010 & 2011 & 2012 & 2008 & 2008 & 2009 & 2010 & 2011 & 2012 \\
\hline TLMP2 & - & 903.6 & NA & 1986 & NA & NA & 14.0 & 186.9 & NA & $<1.0$ & NA & NA & $<1.0$ \\
\hline TLMP4 & - & NA & NA & 980 & 3 & 17.6 & 4.1 & NA & NA & $<1.0$ & $<1.0$ & 0.2 & $<1.0$ \\
\hline TLMP5 & - & 628.2 & NA & 52.1 & 40.4 & 3.4 & NA & 86.7 & NA & $<1.0$ & $<1.0$ & $<1.0$ & NA \\
\hline TLMP6 & - & NA & NA & 1120 & $<1.0$ & NA & 215.4 & NA & NA & $<1.0$ & $<1.0$ & NA & 24.5 \\
\hline TLMP7 & - & 555.5 & 555.5 & 37 & 12 & 43.6 & 126.7 & 63.2 & NA & 3 & 4 & 0.25 & 1 \\
\hline CCRP & 10 & 235.9 & NA & 172 & NA & NA & NA & 114.9 & NA & 2 & NA & NA & NA \\
\hline CCRP & 15 & 165.7 & 411 & NA & NA & NA & NA & 66 & 24 & NA & NA & NA & NA \\
\hline COBA1 & - & 355.5 & NA & NA & NA & NA & NA & 7.3 & NA & NA & NA & NA & NA \\
\hline СОВА2 & - & 475.5 & NA & NA & NA & NA & NA & 5.5 & NA & NA & NA & NA & NA \\
\hline TANK-HA & $<1$ & 728.9 & NA & NA & NA & NA & NA & 12 & NA & NA & NA & NA & NA \\
\hline \multicolumn{14}{|c|}{$\mathrm{NA}=$ no analysis } \\
\hline
\end{tabular}


Table 3. Results for Bacteroides markers in December 2008, March 2009, and July 2009.

\begin{tabular}{cccccccc}
\hline & & \multicolumn{3}{c}{ AllBac (markers/100mL) } & \multicolumn{3}{c}{ HuBac (markers/100mL) } \\
\hline Site & Depth (mbwl) & DEC & MAR & JUL & DEC & MAR & JUL \\
\hline TLMP1 & 6 & $1.04 \times 10^{5}$ & $1.02 \times 10^{5}$ & $4.77 \times 10^{3}$ & ND & ND & $1.88 \times 10^{3}$ \\
TLMP2 & - & NA & ND & $1.13 \times 10^{3}$ & NA & ND & $1.17 \times 10^{2}$ \\
TLMP4 & - & NA & ND & $2.19 \times 10^{2}$ & NA & ND & ND \\
TLMP5 & - & NA & $3.46 \times 10^{2}$ & NA & NA & ND & NA \\
TLMP6 & - & NA & ND & $1.55 \times 10^{2}$ & NA & ND & ND \\
TLMP7 & - & NA & $9.45 \times 10^{2}$ & $3.17 \times 10^{2}$ & NA & ND & ND \\
CCRP & 10 & NA & NA & $1.76 \times 10^{2}$ & NA & NA & ND \\
CCRP & 15 & ND & NA & NA & ND & NA & NA \\
CCRP & 36 & ND & NA & NA & NA & NA \\
\hline
\end{tabular}

Table 4. Detection of caffeine, June 2008.

\begin{tabular}{cc}
\hline Location & Caffeine (ppm) \\
\hline TLMP $(1 \mathrm{~m})$ & 3.55 \\
TLMP $1(6 \mathrm{~m})$ & 3.39 \\
TLMP2 & 0.52 \\
TLMP5 & 0 \\
TLMP7 & 0 \\
COBA1 & 0 \\
COBA2 & 0 \\
TANK-HA & 0 \\
\hline
\end{tabular}

in an area that is best described as rural. At the beginning of sampling collection (December 2008), a dump site for household waste was located within a few dozen meters of the well head of TLMP1. In addition, a chicken farm was located west of the well near the Tulum municipal well battery until March 2009. By July of that year, housing construction was visible directly to the north of the well battery, and much of the forested area north of TLMP1 had been cleared. The clearing of forests removes a possible natural water filtration system in the roots provided by the dense foliage $[25,26]$ and thus, the removal of surface vegetation potentially increases the transport of Coliforms and Bacteroides from the surface and into groundwater/drinking water resources.

Fecal contamination was detected in groundwaters of the entire sampling region covered in this study. However, not all fecal contamination could be definitively connected to human sources, since the chemical/biological markers were not detected in most of the positive coliform sites. There is evidence that this pollution could be related to farming activity near the wells, which may also account for the seasonal variation in detection of fecal contamination.

In karst geology, groundwater flow generally follows a preferential path dictated by limestone fissures, and along the Yucatan, such a path could be transversal to the coast [27] but can also be intersected by the complex fractures along the coast. This groundwater flow could effectively transport contamination inland from coastal locations, thus accounting for fecal contamination detected great distances from surface point sources. Thus, the presence of biological contamination may not only impact the local population located downgradient, but the Meso-American Reef may also be negatively impacted. Meacham [21] has mapped a conduit in the Ox Bel Ha cave system that extends at least nine kilometers perpendicular to the coast. The cave/conduit systems suggest that if the microbial contamination reaches these preferred pathways, the contaminants may reach rapidly the Meso-American Reef System.

The results indicate that fecal contamination in groundwater at protected and non-protected sampled sites is occurring. Though a portion of this may be naturally occurring, there is room for alarm due to the high percentage of wells that were tested positive for $E$. coli during this research project. However, bacteriological contamination can be linked to a variety of sources presented along the area of study. Fecal contamination has been occurring long-term (through recent recorded history) throughout the Yucatán Peninsula, Cancun-Riviera Maya and even in Tulum. As the area continues to increase in population there is an increased factor for concomitant rapid rises in contamination of the drinking water supply. Our results confirm that areas with the highest densities in fecal indicator bacteria in groundwater, there also exist detectable levels of caffeine and fecal molecular markers (Bacteriodes). These methods of detection are useful indicators of the predominant anthropogenic activity in the zone. The persistence of fecal contamination results both from seeping leachates produced by the activities surrounding each site and also moves from other areas of infiltration along the complex karst fractures inland.

\section{Acknowledgements}

Funding for this research was provided by Northern Illi- 
nois University's Center for Latino and Latin American Studies, the Geology and Environmental Geosciences department, and Library. This work was also funded by the United States Department of Agriculture, Agricultural Research Service, Water Management Conservation and Research Program.

Leal-Bautista wishes to thank CONACYT-Mexico in supporting her during initial research at Tanka-Ha and Coba sites.

\section{REFERENCES}

[1] E. C. Perry, J. Swift, J. Gamboa, A. Reeve, R. Sanborn, L. Marin and M. Villasuso, "Geologic and Environmental Aspects of Surface Cementation, North Coast, Yucatan, Mexico,” Geology, Vol. 17, No. 9, 1989, pp. 818-821.

[2] L. E. Marin and E. C. Perry, "The Hydrology and Contamination Potential of Northwestern Yucatan, Mexico,” Geofisica Internacional, Vol. 33, No. 4, 1994, pp. 619623.

[3] S. W. McMurry, M. S. Coyne and E. Perfect, "Fecal Coliforms Transport through Intact Soil Blocks Amended with Poultry Manure,” Journal Environmental Quality, Vol. 27, No. 1, 1998, pp. 86-92.

http://dx.doi.org/10.2134/jeq1998.0047242500270001001 $\underline{3 \mathrm{x}}$

[4] N. Goldscheider, J. Meiman, M. Pronk and C. Smart, "Tracer Tests in Karst Hydrogeology and Speleology,” International Journal of Speleology, Vol. 37, No. 1, 2008, pp. 27-40.

[5] Comision Nacional del Agua (CONAGUA), 2012.

[6] J. Alocer, A. Lugo, L. Marin, E. Escobar, "Hydrochemistry of Waters from Five Cenotes and Evaluation of Their Suitability for Drinking-Water Supplies, Northeastern Yucatan, Mexico,” Hydrogeology Journal, Vol. 6, No. 2, 1998, pp. 293-301. http://dx.doi.org/10.1007/s100400050152

[7] C. Graniel, L. Morris and J. Carrillo-Rivera, "Effects of Urbanization on Groundwater Resources of Mérida, Yucatan, Mexico,” Environmental Geology, Vol. 37, No. 4, 1999, pp. 303-312. http://dx.doi.org/10.1007/s002540050388

[8] L. Marin, B. Steinich, J. Pacheco and O. Escolero, "Hydrogeology of a Contaminated Sole-Source Karst Aquifer, Merida, Yucatan, Mexico,” Geofisica Internacional, Vol. 39, No. 4, 2000, pp. 359-365.

[9] J. Pacheco, S. Armando Cabrera, and L. Marin, “Bacteriological Contamination in the Karstic Aquifer of Yucatan, Mexico," Geofisica Internacional, Vol. 39, No. 3, 2000, pp. 285-291.

[10] J. Pacheco, S. Armando Cabrera, L. Marin, B. Steinich and O. Escolero, "Nitrate Temporal and Spatial Patterns in 12 Water Supply Wells, Yucatan, Mexico,” Environmental Geology, Vol. 40, No. 6, 2001, pp. 708-771. http://dx.doi.org/10.1007/s002540000180

[11] P. Beddows, "Where Does the Sewage Go? The Karst Groundwater System of Municipalidad Solidaridad, Quin- tana Roo," Association for Mexican Cave Studies Activities, No. 25, 2002, pp. 47-52.

[12] C. Metcalfe, G. Bouchot, T. Metcalfe, H. Li, P. Beddows and H. Van Lavieren, "Domestic Wastewater as a Source of Contaminants in Freshwater Aquifers in the Mayan Riviera Tourism Region of Mexico,” 2009.

http://www.inweh.unu.edu/Coastal/POPs/2009_Dominica /Metcalfeposter.pdf

[13] H. Hausman, "Responsible Development in Tulum, Mexico: Considering Water Quality and Subaqueous Cave Locations,” MS Thesis, Duke University, Durham, 2009.

[14] L. Marin, “The Role of Science in Managing Yucatan's Groundwater. Sustainable Management of Groundwater in Mexico,” Proceedings of a Workshop, 2007. http://www.nap.edu/catalog/11875.html

[15] P. Beddows, "Conduit Hydrogeology of a Tropical Coastal Carbonate Aquifer: Caribbean Coast of the Yucatan Peninsula,” MS Thesis, McMaster University, Hamilton, 1999.

[16] W. Ward, A. Weidie, M. Brady, J. Wilson and R. Halley, "Geology of the Northeastern Coast of the Yucatan Peninsula,” In: Geology and Hydrogeology of Northeastern Yucatan, Field Trip. New Orleans Geological Society, GCAGS/SEPM Annual Convention, 1978, pp. 33-42.

[17] Y. Moore, R. Stoessell and D. Easley, "Fresh-Water/SeaWater Relationship within a Ground-Water Flow System, Northeastern Coast of the Yucatan Peninsula," Ground Water, Vol. 30, No. 3, 1992, pp. 343-350. http://dx.doi.org/10.1111/j.1745-6584.1992.tb02002.x

[18] W. Back and B. Hanshaw, "Hydrogeochemistry of the Northern Yucatan Peninsula, Mexico with a Section on Mayan Water Practices,” In: Geology and Hydrogeology of Northeastern Yucatan. Field Trip. New Orleans Geological Society, GCAGS/SEPM Annual Convention, 1978, pp. 229-261.

[19] M. Villasuso and R. Ramos, “A Conceptual Model of the Aquifer of the Yucatan Peninsula IN: Population, Development, and Environment on the Yucatan Peninsula: From Ancient Maya to 2030,” International Institute for Applied Systems Analysis, Laxenburg, 2000.

[20] E. Perry, G. Velazquez-Oliman and L. Marin, "The Hydrogeochemistry of the Karst Aquifer System of the Northern Yucatan Peninsula, Mexico,” International Geology Review, Vol. 44, No. 3, 2002, pp. 191-221. http://dx.doi.org/10.2747/0020-6814.44.3.191

[21] S. Meachem, "Freshwater Resources in the Yucatan Peninsula. Sustainable Management of Groundwater in Mexico,” Proceedings of a Workshop, 2007. http://www.nap.edu/catalog/11875.html.

[22] Comisión Nacional del Agua (CNA), "Precipitacion Media Estatal," 2008.

http://smn.cna.gob.mx/climatologia/precipitacion/estados/ est-2008.gif

[23] Comisión Nacional del Agua (CNA), "Servicio Meteorológico Nacional,” 2009.

http://smn.cna.gob.mx/climatologia/termperaturas/media/t med2009.pdf

[24] US EPA, “Analytical Methods: Contaminants of Emerg- 
ing Concern Pharmacetuicals \& Personal Care Products,” Water, 2007.

[25] S. Pueppke and M. Hawes, "Understanding the Binding of Bacteria to Plant Surfaces,” Trends in Biotechnology, Vol. 3, No. 12, 1985, pp. 311-313. http://dx.doi.org/10.1016/0167-7799(85)90034-4

[26] R. Maier, I. Pepper and C. Gerba, “Environmental Micro- biology,” 2nd Edition, Academic Press, Amsterdam, 2009.

[27] P. Bauer-Gottwein, B. R. N. Gondwe, G. Charvet, L. Marin, M. Rebolledo Vieyra and A. G. Merediz, "Review: The Yucatan Peninsula Karst Aquifer,” Hydrogeology Journal, Vol. 19, No. 3, 2011, pp. 507-524. http://dx.doi.org/10.1007/s10040-010-0699-5 